\title{
COMMERCIAL BEHAVIOUR OF SMALLHOLDER POTATO PRODUCERS: THE CASE OF KOMBOLCHAWOREDA, EASTERN PART OF ETHIOPIA
}

\author{
Kumilachew Alamerie Melesse ${ }^{I}$
}

\begin{abstract}
Meeting the challenge of improving rural incomes in Ethiopia will require some form of transformation of the subsistence, low-input and low-productivity farming systems to agricultural commercialization. In the process, commercial production of high value food crops like potato would have been expected. Nonetheless, in the study area, Kombolcha Woreda, the extent to which farmers have commercialized potato production was not known. This study was then undertaken to analyse the extent to which potato was oriented towards the market (denoted by commercialization index) and identify the factors affecting commercialization of potato. A multi-stage sampling technique was used to select 130 sample households from six sample kebeles. In the study, both primary and secondary data sources were used. Results showed that potato production was lucrative and semi-commercialized i.e. about $59.50 \%$ of the potato produce were sold. Moreover, the two limit-Tobit regression model results indicated that non/off farm income, access to information, access to improved seed and access to irrigation affect proportion of the value of potato sold positively and significantly while number of plots affects it negatively. Hence, policies should emphasis on reducing land fragmentation, creating awareness on non/off farm employment, and offer improved seeds and irrigation facilities to farmers and access information.
\end{abstract}

Keywords: Commercialization, commercialization index, potato, profitability, two limit Tobit

JEL: $D 22, O 13, Q 12, Q 13$

\section{Introduction}

The economy of Ethiopia remains highly dependent on agriculture, which contributes about 41 percent of GDP, 83 percent of employment and 90 percent of exports (EEA, 2012). Smallholder agriculture remains an important source of livelihoods for a majority of the rural population. It serves as a livelihood strategy for poor people engaged in production and marketing of agricultural produces. However, Ethiopian agriculture is dominated by subsistence, low input-low output; rain-fed farming system (MoARD,

1 Lecturer, Kumilachew Alamerie Melesse Haramaya University, School of Agricultural Economics and Agribusiness, P.O. Box no. 95, Dire Dawa, Ethiopia. E-mail: kalamerie@gmail.com

EP 2016 (63) 1 (159-173) 
2010). Most smallholder farmers in Ethiopia still cultivate using hoe technology and rely heavily on family labour. The farming system is focussed on producing food staples to meet subsistence needs. In many parts of the country, market participation of smallholder family farms are limited and agricultural markets are fragmented and not well integrated into wider market systems, which increases transaction costs and reduces farmers' incentive to produce for the market (Bezabih, 2010, Mitku, 2014). As a result, the livelihood and food security situation of the rural population is getting unstable; and smallholder farmers remain prone to income risk. Thus, with the ever-increasing population and the limited farmland, meeting the challenge of improving rural incomes will require some form of transformation of the subsistence, low-input and low-productivity farming systems to agricultural commercialization.

Commercialization of agriculture involves a transition from subsistence-oriented to increasingly market-oriented patterns of production and input use. It may be defined as the proportion of agricultural production that is marketed and can be measured along a continuum from zero (total subsistence-oriented production) to unity ( $100 \%$ of production is sold) (Timmer, 1997; Pingali, 1997). Commercialization of agriculture is more than whether or not a cash crop is present to a certain extent in a production system rather it can occur either on the output side of production with increased marketed surplus or on the input side with increased use of purchased inputs. Commercialization is the outcome of a simultaneous decision-making behaviour of farm households in production and marketing (von Braun, Kennedy, 1994) thus, enhancing the links between the input and output sides of agricultural markets (Berhanu, Moti, 2010). It intensifies the use of productivity enhancing technologies on farms, achieve greater output per unit of land and labour expended, produce greater farm surpluses, expand participation in markets and ultimately raise incomes and living standards (Jayne et al., 2011), especially for households that are poor and/or own little land (Rao, Qaim, 2011), thereby realizing poverty reduction and rural development. Besides, commercialization satisfies the rapid growth in consumer demand for affordable, high quality and local produce.

The transformation process from subsistence to semi-commercial and then to a fully commercialized agriculture requires product choice and input use decisions based on the principles of profit maximization. Commercial reorientation of agricultural production occurs for the primary staple cereals as well as for the so-called high value cash crops (Pingali, Rosegrant, 1995). As a strategy, Ethiopia has adopted commercialization of smallholder agriculture for its economic transformation and the agricultural services of extension, credit and input supply are expanding significantly to support commercial transformation, although the dominant player in these services remains to be the public sector (Berhanu, Moti, 2010). Accordingly, farmers have the intention to commercialize high value food crops. One of the more potential and profitable food crops than many others is potato.

As a food crop, potato has a high potential to supply quality food within a relatively short period, which in turn plays an important role in contributing to the household food security, nutritional value; generate income and employment opportunities for the poor households. 
Ethiopia is one of the principal potato producing countries in Africa and probably displays a unique position for having the highest potential area for cultivating potatoes (EARO, 2000). The area under potato production in Ethiopia in the year 2013/14 was about 66,745 hectares with an average national yield of 117 quintal per hectare for the main cropping season. Out of this, the produce in East Hararghe covered 2,207.12 hectares of land with an average yield of 193 quintal per hectare (CSA, 2014). Eastern Hararghe (Haramaya,and Kombolcha Woredas) is one of the major potato producing areas in the country (Bezabih and Hadera, 2007). In addition to satisfying domestic demand, the potato produce in the region is being exported to regional markets like Djibouti and Somalia, and Middle East countries and the Western European countries (Fekadu, Dandena, 2006;EHDA, 2011). For instance, out of the total volume of potato marketed to Somalia, 75 percent is supplied from East Hararghe and about 25 percent from the central part of Ethiopia (Bezabih, 2008). However, the supply is neither sufficient nor constant to satisfy the demand for the market at both market outlets (Bezabih, 2010; Mahlet, et al., 2015). Thus, the production level of the sector requires further expansion to narrow down the gap between the available supply and the demand for domestic and international markets.

Studies on potato (Bezabih, Hadera, 2007) have shown that, given the availability of favourable climatic conditions and irrigation potential of the area, many of the farmers in Kombolcha Woreda are producing potato and supplying for domestic markets like Harar town and Dire Dawa administrative city and neighbouring countries like SomaliaMogadishu. The smallholder farmers in the Woreda are making profit (Bezabih, 2010), though the profit margin is unfairly low compared to traders. Despite the fact that, in the study area, Kombolcha Woreda, the extent to which farmers have commercialized potato production was not known. In addition, in the area, the purpose of potato production (family consumption and/or for sale) varies from situation to situation and person to person. As such, there are tremendous factors, which influence the level of commercialization in potato production. Therefore, this study was mainly devised to find the level of potato commercialization (measured from the output side- a more prevalent way than that of the input side) and identification of factors determining proportion of potato marketed at the household level.

The findings of this study assumed to be very valuable information for further promotion of commercialization of potato production in the study area. This in turn improves the income and food security status of smallholder farmers.

\section{Methodology of the study}

\section{Description of the Study Area}

The study was conducted in Eastern Ethiopia, specifically, in Kombolcha Woreda/District. Kombolcha Woreda, having an area of $446.61 \mathrm{~km}^{2}$, is found in the northern part of East Hararghe zone of Oromia National Regional State. It is located about 514kms southeast of Addis Ababa and 14kms North West of Harar town. Komblocha Woreda is bordered by Haramaya and Jarso woredas, Harari Regional State and Dire Dawa Administrative 
council. The altitude of the Woreda extends between 1200 and 2460 masl. In the woreda, 7 (37\%) Kebeles (peasant associations) are located in the lowlands (Kola) and the remaining $12(63 \%)$ are located in the midland (Woina dega). Rainfall is mainly bi-modal, but it can be erratic as well-the main rainy season is from February to mid-May and from July to end of August. The mean annual rainfall of Kombolcha Woreda ranges from $600 \mathrm{~mm}$ to 900 $\mathrm{mm}$ (KWP, 2011). The Woreda has a total population of about 169,313 and more than $90 \%$ of the population resides in rural areas (CSA, 2013).

In the Woreda, mixed farming system is practiced. The woreda's farming economy is characterized by small and fragmented land holdings. The rain-fed production system is most dominant and is practiced by the majority of the farmers. However, horticultural crops are often produced using irrigation. Farmers produce different crops like sorghum, maize, wheat, haricot bean, and fruits and vegetables. The woreda is one of the major producers of vegetables including potato, onion, cabbage, beetroot, tomato, and lettuce (Bezabih, Hadera, 2007).

\section{Method of Sampling}

A multi-stage sampling technique was used to collect the primary data from farmers. In the first place, Kombolcha Woreda was purposively selected since it is one of the major potato producing areas in Eastern Ethiopia. Then, six potato producing Kebeles in the Woreda were randomly selected. These sample Kebeles are Bilisumma, Kerensa, Walta Lamaan, Kakali, Iftuha and Legehamma. Within each kebele, potato-producing farmers were identified. Finally, 130 sample potato-producing households were selected randomly based on the proportion to the size of number of potato producer households from the selected kebeles. Incidentally, the formula provided by Yamane (1967) was used to determine the sample size (given in Equation.1 below).

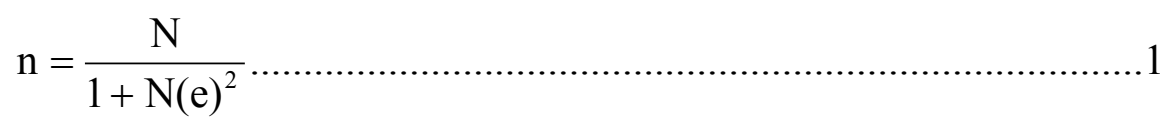

Where, $\mathrm{n}$ is the sample size, $\mathrm{N}$ is the population size, and $\mathrm{e}$ is the level of precision, which equals to $9 \%$. To apply the formula, a $95 \%$ confidence level and estimated proportion of an attribute (participation in potato sale) that is present in the population $(\mathrm{P}=0.5)$ are assumed for the equation.

\section{Method of Data Collection}

For this study, both primary and secondary data sources were used. Primary data were obtained from sample farmers using structured questionnaire through interview. The data collected includes socio-economic characteristics of farmers, land holdings, farming practices, and production and marketing of potato produce. Prior to data collection training was given to the enumerators. Focus group discussions and key informant interviews were also made with community leaders, the Woreda marketing council and market actors in the different markets. Besides, relevant secondary data sources like reports of the Agriculture 
and Rural Development Office of the Woreda, journals, bulletins and unpublished materials were reviewed to supplement the survey data.

\section{Method of Data Analysis}

\section{Descriptive statistics}

The statistical values of mean, standard deviation, percentages and ratios were used to examine and understand the socioeconomic characteristics of sample households. Besides, the profitability of potato production and marketing was evaluated. In the process, gross margin was first estimated by deducting production costs (inputs costs including opportunity costs of family labour) from the gross values of output sold. Finally, the profit per quintal and per ha was estimated by deducting marketing costs and then dividing the end value by the total output and total cultivated area in ha, respectively.

The commercialization index (CI) was also used to determine the level of potato output marketed. Here, the commercialization of potato production was assessed from the output side. Using this approach is more prevalent than from the input side. According to Bekele et al. (2011), Strasberg et al. (1999), and von Braun and Kennedy (1994) the commercialization index for potato production can be defined as:

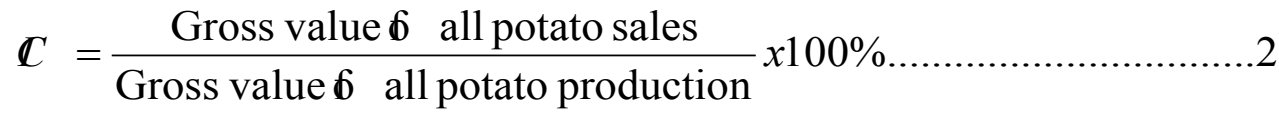

Commercialization index measures the extent to which potato production is oriented towards the market. The index measures the ratio of the gross value of potato sales by a household in a year to the gross value of all potato produced by the same household in the same year expressed as a percentage. Thus, a value of zero would signify a totally subsistence-oriented farmer while the closer the index is to $100 \%$, the higher the degree of market orientation would be (Govereh et al., 1999; Strasberg et al., 1999). The advantage of this approach is that commercialization is treated as a continuum thereby avoiding crude distinction between commercialized and non-commercialized households (Agwu et al., 2013).

\section{Econometric model}

The dependent variable used to measure commercialization behaviour of potato producing sample households is commercialization index. CI is the ratio of the gross value of all potato sales to gross value of all potato production by a household.

The commercialization index is censored because some of its values cluster at the limit (i.e., 0 for subsistence producers and 1 for fully commercialized). Hence, censored regression model is the option for handling this limited dependent variable.

Censored regression models refer to a model in which the dependent variable can be observed only if it is above or below some cut off level. Tobit model is a special case of censored regression models that arise when the dependent variable is limited (or censored) from 
above and/or below. Thus, since the value of the dependent variable, commercialization index, ranges between 0 and 1 inclusive, a two-limit Tobit model has been chosen as a more appropriate econometric model. The two-limit Tobit was originally presented by Rossett and Nelson (1975) and discussed in detail by Maddala (1992) and Long (1997). The twolimit Tobit model can be specified as:

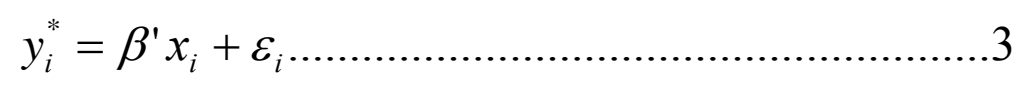

where $y_{i}^{*}$ is a latent variable (unobserved for values smaller than 0 and greater than 1) representing subsistence or fully commercial index; $x_{i}$ is a vector of independent variables, which includes factors affecting output sold; $\beta$ is a vector of unknown parameters; and $\varepsilon_{i}$ is a disturbance term assumed to be independently and normally distributed with zero mean and constant variance $\sigma^{2}$; and $i=1,2, \ldots n(n=$ the number of observations).

Given the observed dependent variable-commercialization index $\left(y_{\mathrm{i}}\right)$, the two limit Tobit model can be specified as:

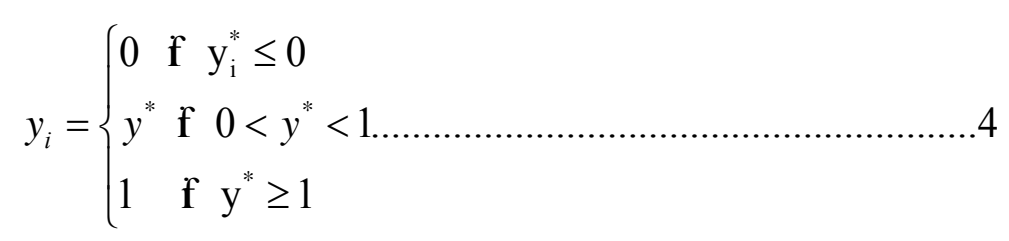

The two limit Tobit model is estimated using maximum likelihood estimation techniques. However, the Tobit coefficients cannot be interpreted directly as estimates of the magnitude of the marginal effects of changes in the explanatory variables on the expected value of the dependent variable. In a Tobit equation, each marginal effect includes both the influence of the explanatory variable on the probability of commercialization as well as on its intensity. More explicitly, the total (marginal) effect takes into consideration that a change in an explanatory variable will affect simultaneously the number of sample farmers to market their production and the extent of output sold. However, which marginal effects should be reported depends on the purpose of the analysis (Greene, 2003). Thus, in this study, the marginal effect results were computed to evaluate the significant effects of the independent variables on the extent of the output sold.

\section{Results and discussion}

\section{Socioeconomic Characteristics of the Sample Households}

The descriptive statistics results of the socioeconomic characteristics of the sample households in Kombolcha Woreda are presented in Table 1 and 2. As shown in Table 1, the majority (about $84 \%$ ) of the respondents were male-headed households. While Table 2 shows that, the average age of the sample household heads is about 36 years and the household heads have about 13 years of potato production experience. The survey results show that $48.5 \%$ of the producers are illiterate while the remaining sample respondents are literate. It was also found that the average schooling level for sample respondents was about 
three grades with a maximum of attending $12^{\text {th }}$ grades. Furthermore, the result revealed that, on average, the family size of sample respondents was about 6 persons per household.

According to the results of the survey, the sample producers use improved seed, local varieties and a combination of both improved and local potato varieties for production purpose accessing from different seed sources. However, out of the total potato producing respondents, only $17.7 \%$ of them used improved seed. In the same period, about $96 \%$ of the respondents used chemical fertilizer to produce potato. On the other hand, in the study area, farmers use irrigation in potato production during the dry seasons. The survey indicates that $76.92 \%$ of those respondents use irrigation for potato production. Most of the farmers rely on boreholes and pond for irrigation. In the region, water-pumping motor (owned or exchanging with labor service for fieldwork or just mutual assistance of the neighbours) plays a great role to undertake the irrigation.

According to the survey result, $23.8 \%$ of the sample potato-producing households had access to credit. The survey result depicts that some sample households are not willing to take loans due to religious reasons (credit is interest bearing).

Access to timely and accurate potato market information is the basic element for producers to decide how much to produce and market at what possible prices. Table 1 revealed that $50.8 \%$ of the total sample households had potato market information.

Despite the huge and extensive investment in promoting extension services in the country, the survey shows that only $59.2 \%$ of the total sample respondents received extension services on potato production. Besides, the contact of potato producers with development agents was not frequent. On average, the farmers visited an extension agent about 10 times in the previous year. Concerning the distance to the nearest market, according to the survey, the respondent farmers are expected to travel an average distance of about $7 \mathrm{~km}$ to reach the nearest market.

Table 1. Summary statistics of sample households (categorical variables)

\begin{tabular}{|l|l|l|}
\hline Variables description & Number of farmers $(\mathrm{N}=130)$ & Percent \\
\hline Sex of household head & & \\
\hline Male & 110 & 84.62 \\
\hline Female & 20 & 15.38 \\
\hline Educational level of household head & & \\
\hline$\quad$ Illiterate & 63 & 48.50 \\
\hline Literate & 67 & 51.50 \\
\hline Access to improved seed(yes) & 23 & 17.7 \\
\hline Access to chemical fertilizer(yes) & 126 & 96.9 \\
\hline Access to irrigation (yes) & 100 & 76.92 \\
\hline Access to credit service(yes) & 31 & 23.8 \\
\hline Access to information(yes) & 66 & 50.8 \\
\hline
\end{tabular}

Source: The author's calculations based on Survey data, 2015 
Table 2: Summary statistics of the sample households (continuous variables)

\begin{tabular}{|l|l|l|l|l|}
\hline Variables description & Mean & Std. Dev. & Min & Max \\
\hline Age of the household head (years) & 35.88 & 10.41 & 20 & 75 \\
\hline Potato production experience (years) & 13.43 & 0.92 & 1 & 50 \\
\hline Family size of the household (persons) & 5.76 & 1.92 & 1 & 11 \\
\hline Distance to nearest market (km) & 7.41 & 7.15 & 0.001 & 22 \\
\hline Extension contact (number) & 10.93 & 15.07 & 0 & 60 \\
\hline
\end{tabular}

Source: The author's calculations based on Survey data, 2015

\section{Sources of Income for the Sample Households}

The farm income is earned from different sources like sales of grains and pulses, chat and coffee, horticultural crops and sales of livestock and livestock products. The average annual farm income of the respondents was Birr 21,565.66. The survey shows that crop production is a major source of income for the majority of the producers. About $52 \%$ of the respondents earn their living from horticulture production (including potato) as a primary source. Chat (Catha edulis) and coffee production are used as a primary source of income for $34.6 \%$ of the households (Table 3). Grains and legume crops such as maize, wheat, sorghum and haricot beans are also used as means of livelihood.

Livestock production is limited by the shortage of grazing area and hence by critical shortage of feed. Average number of livestock for the sample households is 3.17 tropical livestock units (TLU). Only $10 \%$ of the sample respondents depend on livestock production as a major means of livelihood (Table 3 ).

Farmers also participate in non-farm and off-farm activities to generate supplementary income. The farmers in the area generate income from non-farm and off-farm income sources of petty trade, handicraft, daily labor, remittances, aids and working on others farms. About $20 \%$ of the sample producers stated that they participated in non-farm and off-farm income generating activities. The survey indicated that the average annual non/ off-farm income of the sample households was about Birr 1,201.26.

Table 3. Primary source of income of sample households

\begin{tabular}{|l|l|l|}
\hline Income sources/livelihood strategies & $\begin{array}{l}\text { Number of farmers } \\
(\mathrm{N}=130)\end{array}$ & Percent \\
\hline Horticulture production (including potato) & 68 & 52.3 \\
\hline Chat and coffee production & 45 & 34.6 \\
\hline Livestock production & 14 & 10.8 \\
\hline Grain and pulses production & 3 & 2.3 \\
\hline Total & 130 & 100 \\
\hline
\end{tabular}

Source: The author's calculations on the basis of Survey data, 2015 


\section{Land Allocated for Potato Production}

The smallholder farmers' livelihood in Kombolcha Woreda relied on small and fragmented plots. On average, sample respondents have about three plots. According to the survey, the average landholdings of the respondents in the Woreda is less than a hectare $(0.36$ ha on average). Of these, an average of above 0.20 ha of the land is suitable for irrigation (is irrigable area). Overall, the survey results indicate that the proportion of land that is allotted to potato production was about $28.46 \%$. This makes potato a potential vegetable crop around this area.

From the commercial point of view, the average landholding under production was too small to provide any meaningful output for business purposes. However, since the crop is productive and profitable, farmers would increasingly allocate more land to it. This in turn makes commercial potato production more plausible.

\section{Profitability of Potato Production}

According to the survey, the average potato production in the region is about 155 quintals per ha. The information from focus group discussions with traders indicated that, in three production cycles of the year, about 300,100qt of potato was marketed in Kombolcha. Besides selling in Kombolcha, smallholders have alternatives to directly sell their produce including Dire Dawa, Harar and Awodey markets while traders have been involved in both the domestic and export markets. This analysis has assumed all possible markets that the produce can be sold. Based on the survey data, the profitability of production and marketing of potato produce was computed both at per quintal and per ha basis.

The study results revealed that the cost of producing potato in Kombolcha is about Birr 62per quintal and Birr 8,100 per ha. The gross margin of potato is estimated to be Birr 13,900 per ha. Deducting average marketing costs results in a profit of Birr 10,980 per ha for production and marketing of potato. On the other hand, the profit accruing to the farmer by producing a quintal of potato is Birr 97.80. This means potato production in Kombolcha Wordea is a profitable venture.

\section{Commercialization Behaviour of Potato Producers}

Potato is the most commonly grown crop in Kombolcha area in three production cycles. In Cycle I (February to April) and Cycle III (November to January) potato is produced using irrigation while in Cycle II (May to October) potato is produced using rainfall. The production may primarily be meant for consumption or for market.

Some farmers usually produce certain crops for home consumption and some specific crops for sale (Bekele et al., 2011). In this case, the commercial orientation of farmers should be measured with reference to a specific crop rather than the farmer, in general. Thus, this study judged the commercial behaviour of smallholder farmers in potato production using commercialization index. The index was constructed based on productions at the household level. The findings of this study showed that commercialization index for 
sample potato producers was $59.50 \%$. This implies that, on average, $59.50 \%$ of all potato produce was sold. While the remaining output was either consumed or stored as seed tubers for the next season. According to Bekele et al. (2011) and Strasberg et al. (1999), a crop commercialization index greater than $50 \%$ signifies a commercial oriented farmer for a crop under consideration. Since the commercialization index for this study was about $59.50 \%$, then more than half of the potato was produced for sale. The figure indicated that potato production was semi-commercialized. However, the commercialization index of potato was considerably greater than Oromia National Regional State average index (which is $15 \%$ ) and the country average index (which equals to $13 \%$ ) as the study by Pender and Dawit (2007) stated.

\section{Determinants of potato commercialization}

The commercial behaviour of potato producers was measured by commercialization index, which is the ratio of the value of potato sold to the value of all potato, produced in the area in a production year. There are different factors that determine the market oriented behaviour of smallholder farmers in potato production. These determinants were analysed using the two-limit Tobit regression model. The results of the regression are given in Table 4.

Number of plots: this variable is a proxy for land fragmentation. It is negative and significant at $10 \%$ showing that the amount of potato sold decreases as the number of plots increases. Highly fragmented and small parcel size hinders agricultural mechanisation and may require an excessive amount of manual work in the corners and along the boundaries (Burton, 1988), makes supervision and protection of the land difficult, long distances to farms that make labour more costly, loss of working hours, the problem of transporting agricultural implements and products; and results in small and uneconomic size of operational holdings (Bizimana et al., 2004), causes inefficiencies in production and involves large costs to alleviate its effects (Thomas, 2006; Tan et al., 2008). As a result, agricultural productivity and hence income are reduced (Karouzis, 1971). Thus, with a small size and fragmented landholding, production for market would be very difficult. This implies as land fragmentation increases, commercialization orientation of potato decreases. As indicated by the marginal effects, an increase in the number of plots by one will reduce the probability of the proportion of potato marketed by $5.85 \%$ on average.

Non/off farm income: Financial income from non-potato sources had positive effect on commercialization of households and was found to be significant at 5\% probability level. The positive relationship between the variables indicated that any additional financial income increases the proportion of potato marketed by households. Since off-farm and nonfarm income is realized mostly off the season, the involvement in non/off farm activities may enable the farmer to get additional cash income in such a manner that enables the farmer to purchase improved inputs. Moreover, the application of new technology, mainly improved inputs would result quality product, which makes the farmer more competent in the market. Therefore, off/non farm income would improve the benefit from such transactions and encourages the farmer to sell more of potato produced. The marginal effect of the variable also emphasizes that for every increase in one Birr from non-off 
farm income, the probability of the proportion of potato marketed by the household would increase by $0.001 \%$.

Access to market information: Information access is also another factor, which positively affects the proportion of potato sold at $10 \%$ significance level. This result suggested that the proportion of potato marketed increases in response to access to potato market information. Access to information are expected to enhance skills and knowledge of farmers, link farmers with modern technology, and ease liquidity and input supply constraints (Lerman, 2004), thus are expected to induce market orientation(Berhanu, Moti, 2010). The marginal effect of the variable shows that access to market information to potato producers will increase the probability of proportion of potato sold by $11.84 \%$ on average.

Access to irrigation: is measured as the proportion of area irrigated, which was found to be affecting potato commercialization significantly and positively at $1 \%$ probability level. Access to irrigation refers to the physical availability/limitations of irrigation water. Where irrigation is practiced, it allows the extension of the farming season beyond the rainy season. This means farmers having access to irrigation have opportunities to grow potato throughout the year and the produce would be over and above home consumption. This in turn results in farmers having access to irrigation can bring higher proportion of their potato produce to market. Hence, an increase in irrigated area will increase the proportion of potato marketed.

Access to improved seed: is a dummy variable, which was found to be affecting the commercialization index positively and significantly at $10 \%$ significance level. Access to improved seed improves the productivity and quality of output. The increase in productivity brings additional output over and above home consumption. As a result, higher proportion of the output would be supplied to market. As indicated by the marginal effect, access to improved potato seed will increase the probability of the proportion of the value of potato sold by $8.46 \%$.

Table 4.Parameter estimates of two-limit Tobit model for commercialization index

\begin{tabular}{|l|l|l|l|}
\hline Variables & Coef. & Std. Err. & Marginal effect \\
\hline Sex $(1=$ male, $0=$ female) & -0.0449 & 0.0745 & -0.0439 \\
\hline Age (years) & -0.0024 & 0.0024 & -0.0024 \\
\hline Education & -0.0030 & 0.0066 & -0.0029 \\
\hline Landholding (ha) & -0.1122 & 0.1291 & -0.1093 \\
\hline Family size & -0.0035 & 0.0130 & -0.0034 \\
\hline No. of plots & $-0.0648^{*}$ & 0.0345 & -0.0585 \\
\hline Total value of potato produced & $2.53 \mathrm{e}-07$ & $1.15 \mathrm{e}-06$ & $2.46 \mathrm{e}-07$ \\
\hline Livestock size & -0.0083 & 0.0214 & -0.0075 \\
\hline Non-off farm income & $0.00001^{* *}$ & $5.92 \mathrm{e}-06$ & 0.00001 \\
\hline Irrigation access & $1.2530^{* * *}$ & 0.0914 & 1.2197 \\
\hline Access market information & $0.1218^{*}$ & 0.0617 & 0.1184 \\
\hline Improved seed (1=yes, $0=$ no) & $0.0870^{*}$ & 0.0490 & 0.0846 \\
\hline Distance to market & 0.0055 & 0.0043 & 0.0053 \\
\hline Extension contact & 0.0017 & 0.0017 & 0.0017 \\
\hline
\end{tabular}




\begin{tabular}{|l|l|l|l|}
\hline Constant & $0.3423^{* * *}$ & 0.1279 & \\
\hline Sigma & 0.2042 & 0.0163 & \\
\hline
\end{tabular}

Number of observation $=130$

LR $\operatorname{chi}^{2}(14)=200.45$

Prob $>$ chi $^{2} \quad=0.0000$

Log likelihood $=-9.7731$

Pseudo $\mathrm{R}^{2}=0.9112$

Note: $* * *, * *$ and $*$ indicate significance at $1 \%, 5 \%$ and $10 \%$ levels, respectively.

Source: model output based on survey data, 2015

\section{Summary and recommendations}

The objective of this study was to provide empirical findings of commercial behaviour of smallholder potato producers and investigating the factors that affect market orientation/ commercialization of smallholder farmers in Kombolcha Woreda. The descriptive statistics results showed that the proportion of land that was allotted for potato cultivation was about $28.46 \%$ of the total land under cultivation. The profitability analysis indicated that potato production in the region is a rewarding avenue. This study also found that potato production in the Woreda was semi-commercial. This was evidenced by the commercialization index. About $59.50 \%$ of the potato produce was sold. This implies that farmers produced potato both for home consumption and for the market.

Moreover, in this study, the factors that affect commercialization of potato were analyzed using two-limit Tobit regression model. The model results indicated that, non/off farm income, access to information, access to improved seed and access to irrigation determine the proportion of the value of potato sold positively while number of plots affects it negatively and significantly.

The result of the survey indicates that, though potato has been produced in the district and is profitable; it needs further attention to achieve the required commercial stage. Hence, to promote the realization of commercialization of the sector, policies should reduce the problems of land fragmentation through encouraging land consolidation, voluntary parcel exchange and cooperative farming. Likewise, creating awareness on the importance of non/ off farm employment as alternative source of financing/income, delivery of appropriate farm inputs/ improved seeds and construction of irrigation facilities should be given more emphasis to increase the volume of potato marketed. Moreover, up to date market information should be accessible for farmers. 


\section{References}

1. Agwu, N.M., Anyanwu, C.I., Mendie, E.I. (2013): Socio-Economic Determinants of Commercialization among Smallholder Farmers in Abia State, Nigeria. Invited paper presented at the 4th International Conference of the African Association of Agricultural Economists, September 22-25, Hammamet, Tunisia.

2. Bekele, A., Belay, K., Legesse, B., Lemma, T. (2011): Effects of Crop Commercial Orientation on Productivity of Smallholder Farmers in Drought-Prone Areas of the Central Rift Valley of Ethiopia. Journal of Rural Development Vol. 33, No. 4, pp. 105128.

3. Berhanu, G., Moti, J. (2010): Commercialization of Smallholders: Is Market Participation Enough? Contributed Paper presented at the Joint $3^{\text {rd }}$ African Association of Agricultural Economists (AAAE) and $48^{\text {th }}$ Agricultural Economists Association of South Africa (AEASA) Conference, Cape Town, South Africa, September p. 19-23.

4. Bezabih, E., Hadera, G. (2007): Constraints and Opportunities of Horticulture Production and Marketing in Eastern Ethiopia. Drylands Coordination Group Report No. 46.

5. Bezabih, E. (2008): Participatory Value Chain Analysis at Kombolcha District of Eastern Hararghe, Ethiopia. Draft Report, July, 2008. Addis Ababa.

6. Bezabih, E. (2010): Market assessment and value chain analysis in Benishangul Gumuz Regional State, Ethiopia. SID-Consult-Support Integrated Development, Addis Ababa, Ethiopia.

7. Bizimana, C., Nieuwoudt, W.L., Ferrer, S.R.D. (2004). Farm Size, Land Fragmentation and Economic Efficiency in Southern Rwanda. Agrekon, Vol. 43, No. 2, pp. 244-262.

8. Burton, S. (1988): Land Consolidation in Cyprus: A Vital Policy for Rural Reconstruction. Land Use Policy, Vol. 5, No. 1, pp. 131-147.

9. CSA (Central Statistical Agency) (2013): Population Projection of Ethiopia for All Regions at Wereda Level from 2014 - 2017, Addis Ababa, Ethiopia

10. CSA(Central Statistical Authority) (2014): Agriculture Sample Survey 2013/2014 (May, 2014). Report on Area and Production of Major Crops (Private Peasant Holdings, Meher Seasons). Addis Ababa Ethiopia, The FDRE statistical bulletin Volume 01-532.

11. EARO (Ethiopian Agricultural Research Organization) (2000): Potato Long Term Research Strategy. Addis Ababa, Ethiopia.

12. EEA(Ethiopian Economic Association) (2012): Annual Report on Ethiopian Economy. Addis Ababa, Ethiopia.

13. EHDA (Ethiopian Horticultural Development Agency) (2011): Exporting Fruit and Vegetables from Ethiopia: Assessment of Development Potentials and Investment Options in the Export-Oriented Fruit and Vegetable Sector. Addis Ababa, Ethiopia

14. Fekadu, M., Dandena, G. (2006): Review of the status of vegetable crops production and marketing in Ethiopia. Uganda Journal of Agricultural Sciences, Vol. 12, No. 2, 
pp. 26-30.

15. Greene, W. H. (2003): Econometric Analysis. $5^{\text {th }}$ Edition, Prentice-Hall, Pearson Education, Inc., Upper Saddle River, New Jersey, New York University.

16. Govereh, J., Jayne, T.S., Nyoro, J. (1999): Smallholder commercialization, interlinked markets and food crop productivity: Cross-country evidence in eastern and southern Africa, available at: http://www.aec.msu.edu/fs2/ag_transformation/atw_govereh.PDF

17. Jayne, T.S., Haggblade, S., Minot, N., Rash, S. (2011): Agricultural Commercialization, Rural Transformation and Poverty Reduction: What Have We Learned about How to Achieve This? Synthesis Report Prepared for The Alliance for Commodity Trade in Eastern and Southern Africa, Kigali Rwanda.

18. KWP (KombolchaWoreda Profile). (2011): Socio-economic Profile of the Kombolcha Woreda, Ethiopia.

19. Karouzis, G. (1971): Time-Wasted and Distance Travelled by the Average Cypriot Farmer in Order to Visit His Scattered and Fragmented Agricultural Holding. Geographical Chronicles: Bulletin of the Cyprus Geographical Association, Vol. 1, No. 1, pp. 39-58.

20. Long, S. (1997): Regression Models for Categorical and Limited Dependent Variables. Thousand Oaks, CA: Sage publications.

21. Lerman, Z. (2004): Policies and Institutions for Commercialization of Subsistence Farms in Transition Countries. Journal of Asian Economics, Vol. 15, No. 3, pp. 461479.

22. Maddala, G.S. (1992): Introduction to Econometrics Second Edition. Macmillan Publishing Company, New York.

23. Mahlet, A., Bezabih, E., Mengistu, K., Jeffreyson, K.M., Jemal, Y. (2015): Gender role in market supply of potato in Eastern Hararghe Zone, Ethiopia. African Journal of Agricultural Marketing Vol. 3, No. 8, pp. 241-251.

24. MoARD (Ministry of Agriculture and Rural Development) (2010): Ethiopia's Agricultural Sector Policy and Investment Framework (PIF):2010-2020 Draft Final Report 15 September 2010.

25. Mitku, A. (2014): Impact of smallholder farmers' agricultural commercialization on rural households' poverty. International Journal of Applied Economics and Finance Vol. 8, No. 2, pp. 51-61.

26. Pender, J., Dawit, A. (2007): Determinants of Smallholder Commercialization of Food Crops: Theory and Evidence from Ethiopia. IFPRI Discussion Paper 00745

27. Pingali, P. (1997). From subsistence to commercial production System: The transformation of Asian agriculture. American Journal of Agricultural Economics Vol. 79, No. 2, pp. 628-634.

28. Pingali, L.P., Rosegrant, M.W. (1995): Agricultural commercialization and diversification: Process and polices. Food Policy Vol. 20, No. 3, pp. 171-185. 
29. Rao, E. J. O., Qaim, M. (2011): Supermarkets, Farm Household Income, and Poverty: Insights from Kenya. World Development, Vol. 39, No. 5, pp. 784-796.

30. Rosett, R., Nelson, F. (1975): Estimation of the Two-limit probit Regression Model. Econometrica, Vol. 43, pp. 141-146 (DOI: 10.2307/1913419).

31. Strasberg, P.J., Jayne, T.S., Yamano, T., Nyoro, J., Karanja, D., Strauss, J. (1999): Effects of Agricultural Commercialization on Food Crop Input Use and Productivity in Kenya. Office of Sustainable Development; Policy Synthesis for USAID-Africa Bureau, pp. 41.

32. Tan, S., Heerink, N., Kruseman, G., Qu, F. (2008): Do fragmented landholdings have higher production costs? Evidence from rice farmers in Northeastern Jiangxi province, P.R. China, China Economic Review, Vol. 19, No. 3, pp. 347-358 (doi:10.1016/j. chieco.2007.07.001).

33. Timmer, C.O. (1997): Farmers and Markets: the Political Economy of New Paradigms, American Journal of Agricultural Economics, Vol. 79, No. 2, pp. 621-627 (available at: http://www.jstor.org/stable/1244161).

34. Thomas, J. (2006): Property Rights, Land Fragmentation and the Emerging Structure of Agriculture in Central and Eastern European Countries, Journal of Agricultural and Development Economics Vol. 3, No. 2, pp. 225-275.

35. von Braun, J., Kennedy, E. (eds) (1994): Agricultural Commercialization, Economic Development, and Nutrition. The Johns Hopkins University Press, Baltimore and London, pp.11-33.

36. Yamane, T. (1967): Statistics: An Introductory Analysis, $2^{\text {nd }}$ Ed., New York: Harper and Row. 